International Journal of Current Microbiology and Applied Sciences

ISSN: 2319-7706 Volume 6 Number 1 (2017) pp. 917-921

Journal homepage: http://www.ijcmas.com

Original Research Article

http://dx.doi.org/10.20546/ijcmas.2017.601.108

\title{
Efficacy of Botanicals and Bio-agents against Web blight in Mungbean (Vigna radiata L. Wilczek)
}

\author{
Vikas Kumar Singh ${ }^{1}$, Sunil Zacharia ${ }^{1}$, C.K. Singh ${ }^{1}$, R.K. Singh ${ }^{2}$, \\ Dharmendra Singh $^{3}$ and R.K. Pandey ${ }^{2}$
}

${ }^{1}$ Department of Plant Pathology, Sam Higginbottom Institute of Agriculture and

Technology \& Sciences, Allahabad - 211007, (UP), India

${ }^{2}$ Department of Extension Education, N. D. U. A. \& T, Kumarganj, Faizabad-224229 (UP), India

${ }^{3}$ Department of Plant pathology, NDUAT Kumarganj Faizabad 224229 U.P, India

*Corresponding author

\section{A B S T R A C T}

Keywords

Web blight, mungbean, garlic, neem, onion, Trichoderma viride, Trichoderma harzianum

Article Info

Accepted: 28 December 2016 Available Online: 10 January 2017
Three botanicals viz. Neem (Azadirachta indica), Garlic (Allium sativum), Onion (Allium cepa) and a chemicals carbendazim(treated) were used in vivo (in field) at 10 per cent and $0.1 \%$ concentration. To check the disease intensity of web blight in mungbean. The minimum disease intensity and maximum disease control were recorded in garlic(value) followed by neem, onion, Trichoderma viride, $T$. harzianum as compared to treated and untreated check. The yield (value) and 100 -seed weight were also recorded maximum in garlic (value) followed by neem, onion, Trichoderma viride, T. harzianum as compared to treated and untreated check. The avoidable loss in yield was recorded maximum in garlic followed by neem, onion, Trichoderma viride, T. harzianum as compared to treated and untreated check. The bio-agents Trichoderma harzianum and Trichoderma viride have been evaluated in field ( $0.5 \%$ concentration spray) also.

\section{Introduction}

Pulses are the essential component in the human diet. These crops are wonderful gift of nature. They are often referred to as "Poor man's meat", since they are cheaper than meat and yet a source of high quality protein, carbohydrates and other essential micro-nutrients. Besides being rich in protein, they also play an important role in sustainable agriculture by enriching the soil through biological nitrogen fixation.

Mungbean (Vigna radiata L. Wilczek) also known as green gram or golden gram is an important pulse crop of India and grown in Kharif, spring and summer seasons. Several factors viz., insect pests and diseases are mostly responsible for its low production mentain losses and losses caused by web blight. Among disease, web blight caused by Rhizoctonia solani Kuhn is one of the most important disease of mungbean. The web blight appears every year at varying intensity and causes heavy losses in yield. The disease has been successfully managed through use of fungicides but due to its high cost and detrimental effect on environment, soil and 
also by kills of non targeted organism(s), its use should be discouraged. Hence, for minimizing the losses caused by web blight need an inexpensive and environmentally safe management practices. Studies were conducted on the disease management with botanicals and bio-agents against $R$. solani Kuhn in different crops including web blight of mungbean.

\section{Materials and Methods}

A Field trial was conducted during Kharif, 2015 crop season in Randomized Block Design with three replications using samart a highly susceptible cultivar to web blight in vivo.

Three different botanicals viz., leaf extracts of Neem, bulb extracts of Garlic and Onion and one chemicals carbendazim and two bioagents Trichoderma harzianum and Trichoderma viride were used and data were record.

Botanicals (Neem, Garlic, Onion and ) 10\%, chemicals (carbendazim) $0.1 \%$ and bioagents (T. harzianum and T. viride) $0.5 \%$ were sprayed four times at 7 days interval starting from first appearance of disease. Control plots were sprayed with same volume of water.

Per cent disease intensity (PDI) was recorded using 1-9 rating scale (Stonehouse, 1994) starting from first appearance of disease at seven days interval calculated as follows:

$$
\mathrm{PDI}=\frac{\text { Sum of all numerical rating }}{\text { Total number of leaves examined } \times \text { maximum grade }} \times 100
$$

Yield (q/ha), 100 seed weight (g) and per cent avoidable loss were also recorded. The per cent disease control (PDC) and the per cent avoidable losses were calculated as follows:

$$
\mathrm{PDC}=\frac{\text { PDI in unprotected plot }-\mathrm{PDI} \text { in protected plot }}{\text { PDI in unprotected plot }} \times 100
$$

Per cent avoidable loss $=\frac{\text { Yield in protected plot }- \text { Yield in unprotected plot }}{\text { Yield in protected plot }} \times 100$

\section{Results and Discussion}

Effect of botanicals and bio-agents on disease intensity and grain yield of mungbean

The effect of foliar spray with botanicals (Neem, Garlic, and Onion), chemicals (treated) and bioagents (T. harzianum and $T$. viride) on disease intensity and grain yield of mungbean were evaluated during Kharif, 2015.

\section{Effect on disease intensity}

The results of foliar spray on disease intensity were ranging from 32.39-76.73 per cent. All of the treatments were superior over to control (water spray) 79.98 per cent. The minimum disease intensity was recorded in treatment $T_{2}$ Garlic (32.39) followed by $T_{1}$ Neem (46.68), $\mathrm{T}_{3}$ Onion (52.39), $\mathrm{T}_{5}$ Trichoderma viride (76.16), $\mathrm{T}_{4}$ T. harzianum (76.73), as compared to treated (30.28) and untreated check (79.98). (table 4.1) 
However, the treatments $\left(\mathrm{T}_{0}, \mathrm{~T}_{4}\right),\left(\mathrm{T}_{0}, \mathrm{~T}_{4}, \mathrm{~T}_{5}\right)$, $\left(\mathrm{T}_{2}, \mathrm{~T}_{6}\right)$ were non significant and statistically at par with each other.

\section{Effect on per cent disease control (PDC)}

The maximum disease control was recorded in treatment $\mathrm{T}_{2}$ (Garlic) (59.50) followed by $\mathrm{T}_{1}$ (Neem) (41.64), $\mathrm{T}_{3}$ (Onion) (34.50), $\mathrm{T}_{5}(T$. viride) (4.78), $\mathrm{T}_{4}(T$. harzianum) (4.06) as compared to treated (62.14) and untreated check (0.00) (table 4.1).

However, the treatments $\left(\mathrm{T}_{6}, \mathrm{~T}_{2}\right)$ and $\left(\mathrm{T}_{5}, \mathrm{~T}_{4}\right)$ were non significant and statistically at par with each other.

\section{Effect on yield}

Maximum yield was recorded in treatment $\mathrm{T}_{2}$ (garlic) $(9.00 \mathrm{q} / \mathrm{ha})$ followed by $\mathrm{T}_{1}$ (neem) (7.80q/ha), $\quad \mathrm{T}_{3}$ (onion) $\quad(7.10 \mathrm{q} / \mathrm{ha}), \quad \mathrm{T}_{5}$ (Trichoderma viride) $(6.00 \mathrm{q} / \mathrm{ha}), \mathrm{T}_{4}$ (Trichoderma harzianum) $(6.00 \mathrm{q} / \mathrm{ha})$ as compared to treated $(10.2 \mathrm{q} / \mathrm{ha})$ and untreated check (4.95 q/ha). Thus, there was no any effect of $T$. viride and $T$. harzianumon yield (Table 4.1).

Table.4.1 Efficacy of botanicals (10\%) and bio-agents (0.5\%) against R. solani on disease intensity and yield of mungbean during Kharif, 2015

\begin{tabular}{|c|c|c|c|c|c|}
\hline Treatment & $\begin{array}{l}\text { Per cent } \\
\text { disease } \\
\text { intensity }\end{array}$ & $\begin{array}{l}\text { Per cent } \\
\text { disease } \\
\text { control }\end{array}$ & $\begin{array}{c}\text { 100-seed } \\
\text { weight (g) }\end{array}$ & $\begin{array}{l}\text { Yield } \\
\text { (q/ha) }\end{array}$ & $\begin{array}{c}\text { Per cent } \\
\text { avoidable } \\
\text { loss }\end{array}$ \\
\hline $\mathrm{T}_{1}(\mathrm{Neem})$ & & & 3.02 & & \\
\hline & 46.68 & 41.64 & & 7.8 & 36.54 \\
\hline $\mathrm{T}_{2}$ (Garlic) & 32.39 & 59.50 & 3.45 & 9.0 & 45.12 \\
\hline $\mathrm{T}_{3}$ (Onion) & 52.39 & 34.50 & 2.72 & 7.1 & 29.89 \\
\hline $\mathrm{T}_{4}($ Trichoderma harzianum) & 76.73 & 4.06 & 2.26 & 6.0 & 16.95 \\
\hline $\mathrm{T}_{5}($ Trichoderma viride $)$ & 76.16 & 4.78 & 2.28 & 6.0 & 17.77 \\
\hline $\mathrm{T}_{6}$ Carbendazim (treated) & 30.28 & 62.14 & 3.75 & 10.2 & 51.23 \\
\hline $1_{0}$ contror (untreated) & 79.98 & 0.00 & 2.25 & 4.95 & 0.00 \\
\hline F- test & $\mathrm{S}$ & $\mathrm{S}$ & S & $\mathrm{S}$ & $\mathrm{S}$ \\
\hline S. Ed. $( \pm)$ & 1.852 & 2.303 & 0.137 & 0.152 & 2.600 \\
\hline C. D. $(P=0.05)$ & 3.925 & 4.881 & 0.291 & 0.323 & 5.513 \\
\hline
\end{tabular}


However, the treatments $\left(\mathrm{T}_{6} \mathrm{~T}_{2},\right),\left(\mathrm{T}_{1} \mathrm{~T}_{3}\right)$ and $\left(\mathrm{T}_{5}, \mathrm{~T}_{4}, \mathrm{~T}_{0}\right)$ were non significant and statistically at par with each other.

\section{Effect on 100-seed weight}

The 100-seed weight was recorded maximum in treatment $\mathrm{T}_{2}$ (garlic) (3.45) ) followed by $\mathrm{T}_{1}$ (neem) (3.02), $\mathrm{T}_{3}$ (onion) (2.72), $\mathrm{T}_{4}$ (Trichoderma harzianum) (2.26), $\mathrm{T}_{5}$ (Trichoderma viride) (2.28) ) as compared to treated (3.75) ) and untreated check (2.25). The 100-seed weight of treatment $\mathrm{T}_{6}$ significantly superior to rest of the treatments. Thus, there was no any effect on 100 seed weight in $T$. viride and $T$. harzianum sprayed plots (table 4.1). However, the treatments $\left(\mathrm{T}_{4} \mathrm{~T}_{5}\right)$ were non significant and statistically at par with each other.

\section{Effect on avoidable loss}

Maximum avoidable loss in yield was recorded in treatment $\left(\mathrm{T}_{2}\right)$ garlic (45.12) followed by $\left(\mathrm{T}_{1}\right)$ neem $(36.54),\left(\mathrm{T}_{3}\right)$ onion (29.89), ( $\left.\mathrm{T}_{5}\right)$ Trichoderma viride (17.77), $\left(\mathrm{T}_{4}\right)$ Trichoderma harzianum (16.95) as compared to treated (51.23) and untreated check (0.00). (table 4.1)

However, the treatments $\left(\mathrm{T}_{5} \mathrm{~T}_{4}\right.$, were non significant and statistically at par with each other.

The similar results were also reported by Verma (2011) in pot sown crop of mungbean. This supports the present findings.

Meena et al. (2003) found that bulb extract of Garlic was effective in reducing disease caused by Rhizoctonia solani f. sp. sasakii in maize banded leaf and sheath blight. Ray and Kumar (2008) reported that out of 6 plant extract, Garlic was most effective in managing the aerial blight of soybean caused by Rhizoctonia solani in field. Kansal et al. (2008) found Neem extract was effective against R. solani causing web blight in french bean. These are in support of present findings.

Bio-agents did not show any effect on yield when applied as foliar spray. This might be due to that the conditions were not favorable for increasing the population of bio-agents on the plants. As the bio-agents are mostly soil inhabitants and grow saprophytically in presence of high organic matter in soil and increase their population very fast.

In most of the cases bio-agents have been used either as seed treatments or in soil for suppressing the soil borne pathogen and reducing the disease incidence, through hyperparasitism, antibiosis and competition (Yadav et al., 2005 and Pandey and Upadhyay, 2000).

In present study Garlic, Neem, Onion and Tulsi found effective on disease intensity, per cent disease control, yield and 100-seed weight but bio-agents did not show any effect.

In conclusion, foliar spray of Garlic (Allium sativum) was found most effective in reducing web blight, recorded minimum disease intensity, maximum disease control and maximum 100 -seed weight and increased the grain yield as compared to treated and untreated. The present study was limited to one seasons only, therefore to substantiate the present findings more trials over a period of seasons is needed to come out with sound recommendations.

\section{References}

Dubey, S.C., 2002. Evaluation of Gliocladium virens and Trichoderma viride as foliar sprays against web blight of urd and 
mung. J. Mycol Pl. Pathol. 32 (2): 236237.

Dubey, S.C., Patel, B., 2001. Evaluation of fungal antagonistic Thanatephorus cucumeris causing web blight of urd and mungbean. Indian Phytopathol. 54 (2): 206-209.

Jain, M.K., Kumar, A.K.P., Chaudhary, S., Kumar, S., 2008. Bioefficacy of Trichoderma spp. against management of chickpea damping-off caused by $\mathrm{R}$. solani Kühn. Pl. Archives. 8 (1): 399400.

Kansal, S., Thakur, M.C., Sharma, M., 2008. Integrated management of web blight (R. solani) of french bean with nonchemicals. Indian Phytopathol. 63 (3): 391.

Meena, R.L., Rathore, R.S., Mathur, K., 2003. Efficacy of biocontrol agents against $R$. solani f. sp. sasakii causing banded leaf and sheath blight of maize. J. Mycol. Pl. Pathol. 33 (2): 310-312.

Mishra, B.D., Shahoo, K.C., Ghose, S., Rout, M.K., 2005. In vitro evaluation of plant extracts, oil cakes and agro-chemicals against web blight of green gram caused by R. solani. J. Mycopathol. Res. 43 (2): 255-257.

Muralidharan, K., Reddy, C.S., Krishnaveni, D., Loha, G.S., 2003. Evaluation of plant-derived commercial products for blast and sheath blight control in rice. Indian Phytopath. 56 (1): 151-155.

Pandey K.K., Upadhyay, J.P., 2000. Microbial population from rhizosphere and nonrhizosphere soil of pigeonpea-screening for resident antagonist and mode of mycoparasitism. J. Mycol. Pl. Pathol. 30
(1): 7-10.

Patil, R.N., Raut, S.P., 2004. Screening of bioagents against Rhizoctonia bataticola and Fusarium oxysporum causing root rot and wilt in patchouli. Annl. Pl. Prote. Sci. 12 (2): 457-458.

Ray, A., Kumar, P., 2008. Efficacy of botanicals against Rhizoctonia aerial blight of soybean. International $\mathrm{J}$. of $\mathrm{Pl}$. Sci. 3 (1): 132-136.

Stonehouse, J., 1994. Assessment of bean disease using visual key. Plant Pathology 43 (3): 519-527 pp.

Upmanyu, S., Gupta, S.K., 2005. Evaluation of botanicals in vitro against R. solani Kühn, the incitant of root rot and web blight of french bean. Pl. Dis. Res. 20 (1): 66-68.

Verma, A.K., 2011. Efficacy of certain botanicals and bio-agents against Rhizoctonia solani (kuhn) causing web blight of mungbean (Vigna radiata). M.Sc. (Ag.) Thesis, N.D.U.A. \& T. Kumarganj, Faizabad.

Vincent, J.M., 1947. Distortion of fungal hyphae in the presence of certain inhibitors. Nature 159: 850-853.

Yadav, B.C., 2007. Epidemiology and management of web blight of french bean (Phaseolus vulgaris) caused by $\mathrm{R}$. solani (Kühn) Ph.D. thesis NDUA\&T, Kumarganj, Faizabad.

Yadav, B.C., Gupta, R.P., Singh, R.V., 2005. Comparative performance of Trichoderma spp. as seed dresser and soil application against fusarium wilt of pigeonpea. J. Mycol. Pl. Pathol. 35 (3): 541.

\section{How to cite this article:}

Vikas Kumar Singh, Sunil Zacharia, C.K. Singh, R.K. Singh, Dharmendra Singh and R.K. Pandey. 2017. Efficacy of Botanicals and Bio-agents against Web blight in Mungbean (Vigna radiata L. Wilczek). Int.J.Curr.Microbiol.App.Sci. 6(1): 917-921. doi: http://dx.doi.org/10.20546/ijcmas.2017.601.108 